\title{
Regulation of Murine Type 1 Plasminogen Activator Inhibitor Gene Expression In Vivo \\ Tissue Specificity and Induction by Lipopolysaccharide, Tumor Necrosis Factor- $\alpha$, and Transforming Growth Factor- $\beta$
}

Michael S. Sawdey and David J. Loskutoff

Committee on Vascular Biology, Research Institute of Scripps Clinic, La Jolla, California 92037

\begin{abstract}
The regulation of type 1 plasminogen activator inhibitor (PAI1) gene expression was studied in vivo employing a murine model system. Nuclease protection analysis revealed relatively high concentrations of PAI-1 mRNA in the aorta, adipose tissue, heart, and lungs of untreated CB6 (BalbC $\times$ C57B16) mice. Treatment of CB6 mice with LPS, TNF- $\alpha$, or transforming growth factor- $\beta$ (TGF- $\beta$ ) increased the steady-state levels of PAI-1 mRNA within $3 \mathrm{~h}$ in all tissues examined. However, the greatest responses to TGF- $\beta$ were observed in adipose tissue and the kidney, while LPS and TNF- $\alpha$ strongly stimulated PAI-1 gene expression in the liver, kidney, lung, and adrenals. In $\mathrm{C3H} / \mathrm{HeJ}$ mice, which exhibit defective TNF- $\alpha$ release in response to LPS, the response of the PAI-1 gene to LPS was severely attenuated. However, injection of these mice with TNF- $\alpha$ increased PAI-1 mRNA in a tissue-specific pattern strikingly similar to that observed in LPS-treated CB6 mice. These results demonstrate that the PAI-1 gene is regulated in a complex and tissue-specific manner in vivo, and suggest a role for TNF- $\alpha$ in the response of the PAI-1 gene to sepsis. (J. Clin. Invest. 1991.88:1346-1353.) Key words: gene regulation • fibrinolysis • endotoxin • sepsis • atherosclerosis
\end{abstract}

\section{Introduction}

Type 1 plasminogen activator inhibitor (PAI-1) ${ }^{1}$ is a rapid and specific inhibitor of both tissue- (t-PA) and urokinase- (u-PA) type plasminogen activators (1), and may be the primary regulator of plasminogen activation in vivo (2). Deficiencies in its activity lead to accelerated fibrinolysis and bleeding $(3,4)$, while abnormally high levels are frequently observed in conditions where an increased risk of thrombosis exists. For example, tenfold or greater elevations in PAI-1 activity have been

Address correspondence and reprint requests to Dr. D. J. Loskutoff, Committee on Vascular Biology, Imm-14, Research Institute of Scripps Clinic, La Jolla, CA 92037.

Received for publication 29 April 1991 and in revised form 25 June 1991.

1. Abbreviations used in this paper: $A U$, absorbance units; $\mathrm{CAD}$, coronary artery disease; CB6, BalbC $\times$ C57B16; nt, nucleotide; PAI-1, type 1 plasminogen activator inhibitor; $t$-, $u-P A$, tissue-, urokinase-type plasminogen activator; TGF- $\beta$, transforming growth factor- $\beta$.

J. Clin. Invest.

(c) The American Society for Clinical Investigation, Inc.

0021-9738/91/10/1346/08 \$2.00

Volume 88, October 1991, 1346-1353 detected in the plasma of patients with gram-negative sepsis (5), and during the second and third trimesters of pregnancy (6). Similarly, increases in PAI-1 have been documented in patients with deep vein thrombosis $(7,8)$ and during acute phase reactions after surgery $(9,10)$, trauma $(10,11)$, and myocardial infarction (12).

Elevations in plasma PAI-1 levels may also be present in individuals with metabolic disorders associated with the development of atherosclerosis. Significant correlations have been established between PAI-1 levels and obesity (13), noninsulindependent diabetes (14), hyperinsulinemia (15), and hypertriglyceridemia $(15,16)$. Moreover, PAI-1 activity was shown to be increased in patients with coronary artery disease (CAD) (17), although no such relationship could be demonstrated when hyperlipidemic or diabetic subjects were excluded from consideration (18). These observations imply that elevations in PAI-1 activity, in association with disorders of carbohydrate or lipid metabolism, may contribute to the development of atherosclerosis and CAD (19), and may constitute a risk factor for myocardial infarction $(16,20)$.

The mechanisms underlying these alterations in plasma PAI-1 activity are largely unknown. In vitro, PAI-1 is synthesized and secreted by a variety of cell types, including cultured endothelial cells of arterial, venous, and microvascular origin, as well as smooth muscle cells, kidney mesothelial and tubular epithelial cells, lung fibroblasts, hepatocytes, and several transformed cell lines (for review, see reference 2). Its synthesis in cells is positively regulated by many agents. These include: LPS, the toxic principle of gram-negative bacteria; the inflammatory cytokines interleukin 1 and TNF- $\alpha$; growth factors such as transforming growth factor- $\beta$ (TGF- $\beta$ ), basic fibroblast growth factor, and epidermal growth factor; and hormones, such as glucocorticoids and insulin. Many of these agents have been shown to increase the accumulation of PAI-1 mRNA, and to stimulate PAI-1 gene transcription (reviewed in references 2 and 21).

Despite these findings, little is known concerning the regulation of PAI-1 biosynthesis in vivo. Here we demonstrate the presence of relatively high concentrations of PAI- 1 mRNA in the aorta, adipose tissue, heart, and lungs of normal mice, implicating these tissues as active sites of PAI-1 biosynthesis. We show further that experimental administration of LPS leads to an increased accumulation of PAI-1 mRNA in all tissues examined, consistent with its induction in vascular cells. A similar tissue-specific response pattern is elicited by TNF- $\alpha$, suggesting that the response of the PAI-1 gene to sepsis may result in part from increases in circulating TNF- $\alpha$. Finally, we show that a distinct pattern of PAI-1 gene expression is observed in response to TGF- $\beta$, suggesting that the effects of this growth factor may be targeted to different cell types in vivo. 


\section{Methods}

Experimental protocols. Adult male CB6 mice (BalbC/ByJ $\times$ C57B16/ $\mathrm{J}$; Scripps Clinic Rodent Breeding Colony) or $\mathrm{C} 3 \mathrm{H} / \mathrm{HeJ}$ mice (Jackson Laboratory, Bar Harbor, ME) weighing 25-30 g were employed for all experiments. LPS (Escherichia Coli serotype 0111:B4; Sigma Chemical Co., St. Louis, MO) or recombinant human TNF- $\alpha$ (Boehringer Mannheim, Indianapolis, IN) were diluted to the appropriate concentration in $300 \mu \mathrm{l}$ sterile saline (Baxter, Deerfield, IL) and injected intraperitoneally into mice anesthetized by inhalation of metofane (methoxyflurane; Pitman-Moore, Mundelein, IL). In some experiments, control mice were anesthetized and injected with an equivalent volume of saline alone. Recombinant human TGF- $\beta$ type 1 , dissolved in $5 \mathrm{mM}$ $\mathrm{HCl}$, was a generous gift of Berlex Biosciences, South San Francisco, CA. The TGF- $\beta$ was diluted into $300 \mu$ l saline and administered to mice by intravenous injection in the tail vein. Control animals received injections of an equivalent dilution of $5 \mathrm{mM} \mathrm{HCl}$. At the conclusion of experiments, mice were anesthetized by metofane inhalation and killed by cervical dislocation. Tissues were rapidly removed by standard dissection techniques, minced, and immediately frozen in liquid nitrogen.

Preparation of RNA. Total RNA was prepared from frozen tissues by the acid guanidium thiocyanate-phenol-chloroform method (22), and its concentration was determined by sample absorbance at 260 $\mathrm{nm}$. Average yields of total RNA per tissue were calculated based upon yields from at least ten independent preparations.

Probes. Plasmids containing cDNA inserts derived from murine PAI-1 cDNA (23) or rat ribosomal rDNA (24) were obtained as kind gifts from Dr. L. Diamond (DNX, Princeton, NJ) and Dr. L. Rothblum (Baylor College of Medicine, Houston, TX), respectively. For nuclease protection assays, a $0.5-\mathrm{kb}$ antisense PAI-1 RNA probe, complementary to $\mathbf{4 4 5}$ nucleotides (nt) of the $5^{\prime}$ region of mouse PAI-1 mRNA, was radiolabeled by in vitro transcription of the murine PAI-1 cDNA template in the presence of $\left[\alpha^{32} \mathrm{P}\right] \mathrm{CTP}(>3,000 \mathrm{Ci} / \mathrm{mmol}$; Amersham Corp, Arlington Heights, IL) and purified by preparative electrophoresis on $6 \%$ polyacrylamide gels (25). For slot-blot hybridizations, the rat $18 \mathrm{~s}$ rDNA probe was radiolabeled by the random primer technique (26) employing [ $\left.\alpha{ }^{32} \mathrm{P}\right] \mathrm{dGTP}(>3,000 \mathrm{Ci} / \mathrm{mmol}$; Amersham Corp.).

Nuclease protection assay. To determine the PAI-1 mRNA concentration in samples of total RNA, a ribonuclease protection assay (25) was employed. Preparations of total RNA (10-20 $\mu \mathrm{g})$ were resuspended in $40 \mu$ of hybridization buffer ( $40 \mathrm{mM}$ PIPES, pH 6.4, $0.4 \mathrm{M} \mathrm{NaCl}$, $1.25 \mathrm{mM}$ EDTA, $80 \% \mathrm{vol} / \mathrm{vol}$ formamide) and $2.0 \mu \mathrm{l}$ aliquots removed for separate determination of 18s RNA content (see below). Hybridization buffer $(5.0 \mu \mathrm{l})$, containing $5.0 \times 10^{5} \mathrm{cpm}$ probe and $1.2 \mathrm{pg}$ of a synthetic sense strand PAI-1 RNA control, was added to each total RNA sample. The samples were then denatured at $85^{\circ} \mathrm{C}$ for 3 min and hybridized at $45^{\circ} \mathrm{C}$ for a minimum of $8 \mathrm{~h}$. After hybridization, samples were incubated with $40 \mu \mathrm{g} / \mathrm{ml}$ ribonuclease $A$ (Boehringer Mannheim) and $2 \mu \mathrm{g} / \mathrm{ml}$ ribonuclease T1 (GIBCO BRL, Grand Island, NY) for $1 \mathrm{~h}$ at $23^{\circ} \mathrm{C}$ and processed as described $(25)$. For analysis of results, samples were electrophoresed on $6 \%$ polyacrylamide sequencing gels. The gels were fixed and dried by standard procedures and autoradiographed on XAR-5 film (Eastman Kodak, Rochester, NY) at $-80^{\circ} \mathrm{C}$ with intensifying screens.

Quantitation of PAI-1 mRNA. The level of PAI-1 mRNA was quantitated either by densitometric analysis of protection assay autoradiograms, employing an LKB Ultroscan XL laser densitometer (LKB, Bromma, Sweden), or by direct $\beta$-scanning of dried gels, employing an AMBIS radioanalytic imaging device (Automated Microbiology Systems, San Diego, CA). For densitometric analysis, the linear range of measurement was established by comparing relative values from densitometric scans (absorbance $\mathrm{U} / \mathrm{mm}^{2}$ peak area; $A U / \mathrm{mm}^{2}$ ) with $\beta$-scanning results (cpm). The peak area defined by the 445-nt PAI-1 mRNA protection fragment (see Fig. 1) typically contained $60-80 \%$ of the total radioactivity per lane when analyzed by $\beta$-scanning.

To normalize for variability in sample loading, aliquots of protection assay samples were slot-blotted and hybridized to a ${ }^{32} \mathrm{P}$-labeled rat 18s rDNA probe as described (27). Relative values for 18s RNA content were obtained for each sample by densitometric scanning of slotblot autoradiograms. To provide normalization factors for the estimation of PAI-1 mRNA content (see below), the $18 \mathrm{~s}$ values for each sample were divided by the mean $18 \mathrm{~s}$ relative value for each experiment.

To determine the absolute amount of PAI-1 mRNA in each sample, a 96-nt synthetic PAI-1 RNA standard was synthesized by in vitro transcription and purified by preparative electrophoresis on a $6 \%$ polyacrylamide sequencing gel. Identical amounts $(1.2 \mathrm{pg})$ of this standard were added to each hybridization reaction to generate an 80-nt protected fragment corresponding to $1.0 \mathrm{pg}$ PAI-1 RNA in each lane. The quantity of full length (i.e., $3.2 \mathrm{~kb}$ ) (23) murine PAI-1 mRNA was estimated in relation to this standard as follows:

$\frac{\mathrm{cpm}\left(\text { or } A U / \mathrm{mm}^{2} \text { ) per 445-nt fragment }\right.}{\text { cpm (or } A U / \mathrm{mm}^{2} \text { ) per 80-nt fragment }}=$ pg 445-nt fragment;

(pg 445-nt fragment) $\times \frac{3.2 \mathrm{~kb}}{0.445 \mathrm{~kb}}=$ pg $3.2 \mathrm{~kb}$ PAI-1 mRNA;

(pg $3.2 \mathrm{~kb}$ PAI-1 mRNA) $\times \frac{\text { mean } 18 \mathrm{~s} A U / \mathrm{mm}^{2}}{18 \mathrm{~s} A U / \mathrm{mm}^{2}}$

= pg $3.2 \mathrm{~kb}$ PAI-1 mRNA (normalized for variation in 18s RNA).

The concentration of PAI-1 mRNA for each sample was expressed as $\mathrm{pg} / \mu \mathrm{g}$ total RNA assayed.

\section{Results}

To examine expression of the PAI-1 gene in vivo, total RNA was extracted from tissues of adult male CB6 mice and the level of PAI-1 mRNA determined by ribonuclease protection assay (see Methods). Results from a representative animal are shown in Fig. $1 A$. PAI-1 mRNA was detected in all tissues examined, although its concentration varied considerably. Relatively high levels were apparent in aorta, adipose tissue, heart, and lung, while intermediate levels were detected in muscle, adrenals,
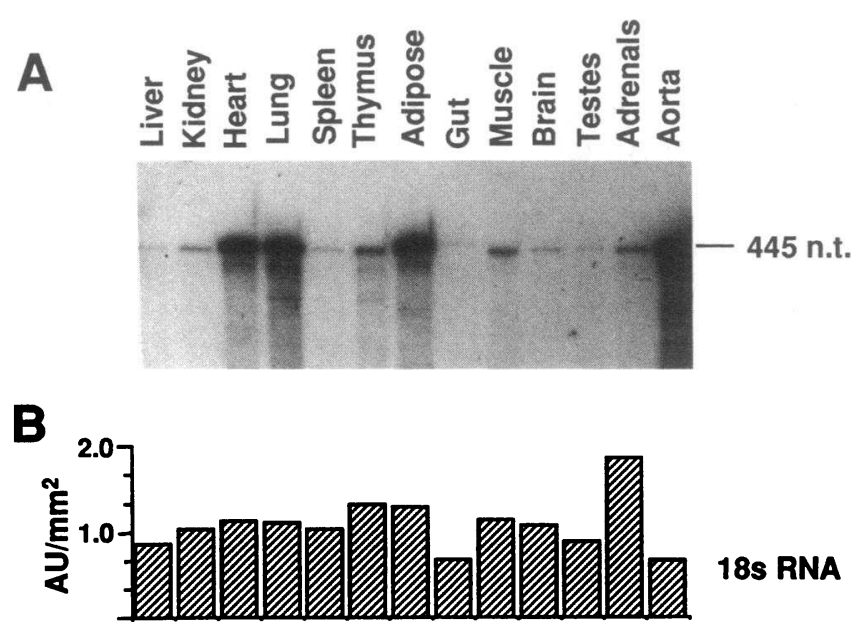

Figure 1. Tissue specificity of murine PAI-1 gene expression. $(A)$ Total RNA was prepared from the indicated tissues, and $10 \mu \mathrm{g}$ was analyzed for PAI-1 mRNA content by ribonuclease protection assay (see Methods). The 445-nt protection fragment derived from murine PAI-1 mRNA is indicated. The autoradiogram was exposed for $10 \mathrm{~d}$. (B) The 18s ribosomal RNA content of each total RNA sample was determined separately by slot-blot hybridization. The results were quantitated by scanning densitometry and are presented beneath each lane. 
Table I. Quantitative Analysis of PAI-1 Gene Expression in Murine Tissues

\begin{tabular}{lccc}
\hline \multicolumn{1}{c}{ Tissue } & PAI-1 mRNA* $^{*}$ & $\begin{array}{c}\mu g \text { total RNA } \\
\text { tissue }\end{array}$ & $\begin{array}{c}\text { pg PAI-1 mRNA } \\
\text { tissue }\end{array}$ \\
\hline Liver & $0.021 \pm 0.007$ & 8,745 & 184 \\
Kidney & $0.091 \pm 0.031$ & 1,160 & 106 \\
Heart & $0.583 \pm 0.149$ & 164 & 95 \\
Lung & $0.351 \pm 0.196$ & 267 & 94 \\
Adipose & $0.606 \pm 0.070$ & 65 & 39 \\
Testes & $0.024 \pm 0.010$ & 613 & 15 \\
Brain & $0.026 \pm 0.009$ & 542 & 14 \\
Thymus & $0.048 \pm 0.028$ & 179 & 9 \\
Aortall & $2.018 \pm 0.358$ & 4 & 8 \\
Spleen & $0.019 \pm 0.007$ & 337 & 6 \\
Adrenals & $0.079 \pm 0.020$ & 19 & 1 \\
Muscle' & $0.180 \pm 0.102$ & & \\
\end{tabular}

PAI-1 mRNA concentrations for the indicated tissues were determined by analysis of ribonuclease protection assay results from three adult male CB6 mice as described in Methods. * pg PAI-1 mRNA/ $\mu \mathrm{g}$ total RNA \pm SD. ${ }^{\ddagger}$ Average of 10 or more preparations. ${ }^{8}$ Epididymal fat pad. "Thoracic aorta. 'Skeletal muscle (hindlimb); total yield not determined.

kidney, and thymus. Low levels were present in liver, spleen, gut, brain, and testes. To assess for variation in RNA loading, the $18 \mathrm{~s}$ ribosomal RNA levels of each sample were determined separately by slot-blot hybridization (see Methods), and are shown in Fig. $1 B$.

To determine the average concentration of PAI-1 mRNA in the various tissues, multiple animals were analyzed as in Fig. 1. The amount of PAI-1 mRNA in total RNA samples from each tissue was then determined by direct comparison to a synthetic RNA standard (see Methods), and its concentration expressed as $\mathrm{pg} / \mu \mathrm{g}$ total RNA (Table I). While some variation was noted between animals, a pattern of gene expression consistent with that depicted in Fig. 1 was revealed. The aorta contained the highest concentration of PAI-1 mRNA (2.018 $\mathrm{pg} / \mu \mathrm{g}$ total RNA), followed by adipose tissue $(0.606 \mathrm{pg} / \mu \mathrm{g})$, heart $(0.583 \mathrm{pg} / \mu \mathrm{g})$, and lung $(0.351 \mathrm{pg} / \mu \mathrm{g})$. Considerably lower concentrations were detected in the liver $(0.021 \mathrm{pg} / \mu \mathrm{g})$, kidney $(0.091 \mathrm{pg} / \mu \mathrm{g})$, and other tissues.

The average yield of total RNA was determined for each tissue and employed to calculate its specific PAI-1 mRNA content (i.e., the total amount of PAI-1 mRNA within the tissue as a whole). The highest amounts of PAI-1 mRNA were present in the liver and kidney, due to the greater total RNA content of these organs (Table I). Relatively high amounts of PAI-1 mRNA were also present in the heart and lung, which contained much lower yields of total RNA, but higher concentrations of PAI-1 mRNA. Intermediate amounts of PAI-1 mRNA were present in adipose tissue. However, this latter estimate reflects only the PAI- 1 mRNA content of epididymal fat, and thus excludes the potential contribution of other murine fat deposits (e.g., retroperitoneal or subcutaneous).

Treatment with LPS has previously been shown to increase plasma PAI-1 activity in rabbits (5) and rats (28), as well as in human volunteers (29). To assess the effect of LPS on murine PAI-1 gene expression, mice were injected intraperitoneally with $50 \mu \mathrm{g}$ LPS $(2.0 \mathrm{mg} / \mathrm{kg})$ or with saline vehicle. Tissues were removed $3 \mathrm{~h}$ later, and total RNA was prepared and analyzed for PAI-1 mRNA as above. The results are presented in Fig. 2, with the optimal autoradiographic exposure time shown for each tissue (see legend to Fig. 2). Increases in PAI-1 mRNA were detected in all 13 tissues examined, although the extent of induction varied considerably. Quantitative analysis of data from two replicate experiments was performed employing a $\beta$-scanning device (Table II). The greatest fold induction occurred in the liver (305-fold), followed by the kidney (93-fold), lung (74-fold), and adrenals (28-fold). Increases of 10-fold or less were observed in all other tissues.

To evaluate the time course of this response, mice were injected with $50 \mu \mathrm{g}$ LPS and selected tissues (liver, kidney, heart, and lung) were removed at 1, 3, 8, and 24-h intervals. The PAI-1 mRNA concentrations for these tissues were then determined as above. For each tissue, a detectable increase was observed within $1 \mathrm{~h}$ (Fig. 3). Maximal induction was apparent by $3 \mathrm{~h}$ in the kidney, heart, and lung, and decreased to $40-60 \%$ of maximal levels by $8 \mathrm{~h}$. In contrast, the liver appeared to respond to LPS more slowly, and did not reach the maximal

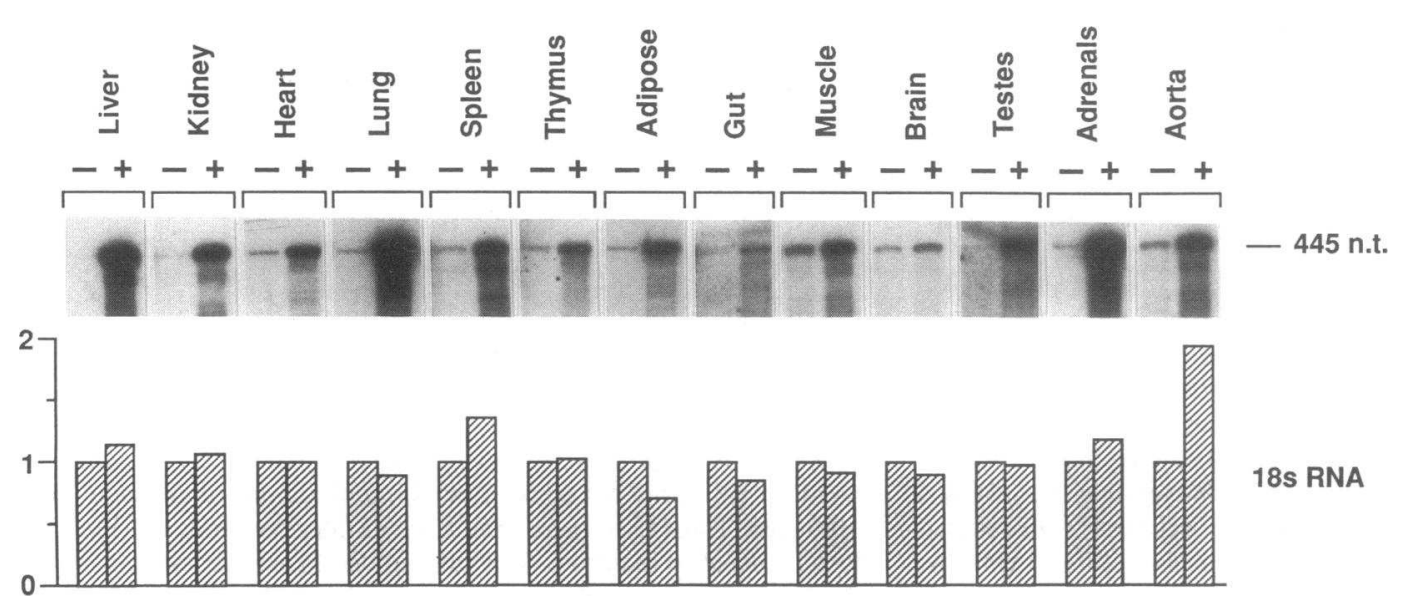

Figure 2. Induction of murine PAI-1 mRNA by LPS. Mice were injected intraperitoneally with either saline $(-)$ or saline containing $50 \mu \mathrm{g}$ LPS (+). The animals were killed $3 \mathrm{~h}$ later and total RNA was prepared from the indicated tissues and analyzed for PAI-1 mRNA by ribonuclease protection assay. The protection fragment corresponding to PAI-1 mRNA (445 nt) is indicated. The $18 \mathrm{~s}$ ribosomal RNA content of each sample is shown in the histogram beneath each lane, with the relative values for control lane samples arbitrarily equalized to 1.0. Autoradiographic exposure times were varied between tissues to permit optimal visualization of control and induced signals, and were as follows: liver, kidney, heart, lung, and adipose, $1 \mathrm{~d}$; adrenals, $2.5 \mathrm{~d}$; spleen, thymus, muscle, brain, and aorta, $5 \mathrm{~d}$; gut, and testes, 2 wk. 
Table II. Comparison of PAI-1 mRNA Induction by LPS, TNF- $\alpha$, and TGF- $\beta$

\begin{tabular}{lrcr}
\hline Tissue & + LPS & + TNF- $\alpha$ & + TGF $-\beta$ \\
\hline Liver & 305 & 26 & 7 \\
Kidney & 93 & 15 & 27 \\
Heart & 4 & 2 & 9 \\
Lung & 74 & 21 & 7 \\
Spleen & 8 & 5 & 6 \\
Thymus & 6 & 4 & ND \\
Adipose & 7 & 9 & 36 \\
Muscle & 5 & 5 & 9 \\
Adrenals & 28 & 27 & ND \\
Aorta & 9 & ND & ND \\
& & & \\
\hline
\end{tabular}

CB6 mice were injected with either $50 \mu \mathrm{g} E$. Coli 0111:B4 LPS, $4.0 \mu \mathrm{g}$ recombinant human TNF- $\alpha, 3.0 \mu \mathrm{g}$ recombinant human TGF- $\beta$, or the appropriate vehicle, and tissues were removed for RNA analysis $3 \mathrm{~h}$ later. PAI- $1 \mathrm{mRNA}$ levels were quantitated by either $\beta$-scanning (LPS, TNF- $\alpha$ ) or densitometric analysis (TGF- $\beta$ ) as described in Methods. Autoradiographic signals employed for densitometric analysis were within the linear range of measurement as established by control experiments. Fold induction values given represent the average of two experiments.

level until $\sim 8 \mathrm{~h}$. The levels of PAI-1 mRNA remained significantly elevated in each tissue at $24 \mathrm{~h}$ after treatment.

The dose dependency of the response to LPS was then examined. CB6 mice were injected with doses of LPS ranging from $0.005-50 \mu \mathrm{g}(0.2 \mu \mathrm{g}-2.0 \mathrm{mg} / \mathrm{kg})$, and the liver, kidney, heart, and lung were removed $3 \mathrm{~h}$ later for analysis. Although PAI-1 mRNA increased in each tissue in a dose-dependent manner (Fig. $4 \mathrm{~A}$ ), significant differences in sensitivity were evident. For example, at the minimal dose tested (5.0 ng LPS), a 24-fold increase was observed in the liver, while lesser responses were observed in the kidney (3.7-fold increase) and lung (2.6-fold increase). PAI-1 mRNA levels in the heart did not increase at this dose. In fact, the heart displayed only a modest increase (1.5-2.1-fold), even when doses of 50-500 ng were employed. At the highest dose tested $(50 \mu \mathrm{g})$, the concentration of PAI-1 mRNA in the heart, kidney, and liver rose to $2.5-4.0 \mathrm{pg} / \mu \mathrm{g}$ total RNA. In contrast, the concentration of PAI-1 mRNA in the lung rose to $33.5 \mathrm{pg} / \mu \mathrm{g}$ at this dose, nearly 10 -fold higher than in the other tissues.

$\mathrm{C} 3 \mathrm{H} / \mathrm{HeJ}$ mice exhibit greatly decreased sensitivity to the toxic effects of LPS. This behavior appears to result from a defect in LPS signal transduction in these animals (30). To assess the role of this signal transduction pathway in the response of PAI-1 mRNA to LPS, $\mathrm{C} 3 \mathrm{H} / \mathrm{HeJ}$ mice were injected with increasing amounts of LPS $(0.005-50 \mu \mathrm{g})$. The mice were killed at $3 \mathrm{~h}$ postinjection and the concentration of PAI-1 mRNA in liver, kidney, heart, and lung was determined as above. In most instances, little change was evident in PAI-1 mRNA levels at doses below $500 \mathrm{ng}$ LPS (Fig. $4 \mathrm{~B}$ ), a dose that resulted in pronounced increases in these tissues in CB6 mice (Fig. $4 \mathrm{~A}$ ). Even at the highest doses employed, relatively minimal increases in PAI-1 mRNA were observed in $\mathrm{C} 3 \mathrm{H} / \mathrm{HeJ}$ mice (Fig. $4 \mathrm{~B}$ ).

These results indicate that the signaling deficit in $\mathrm{C} 3 \mathrm{H} / \mathrm{HeJ}$ mice attenuates the response of the PAI-1 gene to LPS. Because the LPS-mediated release of TNF- $\alpha$ is a primary event in the induction of septic shock (31), and this response is attenuated in $\mathrm{C} 3 \mathrm{H} / \mathrm{HeJ}$ mice (30), we evaluated the response of the PAI-1 gene to TNF- $\alpha$ itself. Recombinant human TNF- $\alpha(0.16 \mathrm{mg} /$ $\mathrm{kg}$ ) was administered to either $\mathrm{CB} 6$ or $\mathrm{C} 3 \mathrm{H} / \mathrm{HeJ}$ mice by intraperitoneal injection, and the tissues were removed $3 \mathrm{~h}$ later for analysis. A response qualitatively similar to that of LPS was observed in CB6 mice (Fig. 5 A; compare to Fig. 2). (Note variation in autoradiographic exposure times in Fig. 2.) The highest concentrations of PAI-1 mRNA after treatment with TNF- $\alpha$ were detected in the lung. In addition, strong responses were observed in the liver and kidney (Fig. 5) and adrenals (not shown). Nearly identical responses were evident in $\mathrm{C} 3 \mathrm{H} / \mathrm{HeJ}$ mice (Fig. $5 B$ ), indicating that the signaling defect in these animals does not extend to TNF- $\alpha$. The fold induction of PAI1 mRNA in response to TNF- $\alpha$ was determined by $\beta$-scanning and is compared with that of LPS in Table II.

TGF- $\beta$, a multifunctional polypeptide present in platelets (32), is also present in monocytes, and is released from monocytes in response to LPS (33). TGF- $\beta$ stimulates PAI- 1 gene expression in a variety of cultured cell types (2), and experimental infusion of TGF- $\beta$ was recently shown to increase plasma PAI- 1 activity in rabbits (34). To examine the effect of TGF- $\beta$ on murine PAI-1 gene expression, CB6 mice were injected intravenously with recombinant human TGF $\beta(0.12 \mathrm{mg} / \mathrm{kg})$ or with saline vehicle. The mice were killed $3 \mathrm{~h}$ later and their tissues removed for analysis. As shown in Fig. 6, TGF- $\beta$ administration increased the level of PAI-1 mRNA in all tissues examined. However, in contrast to LPS and TNF- $\alpha$, the strongest responses to TGF- $\beta$ were observed in adipose tissue and kidney, while considerably less induction of PAI-1 mRNA was observed in the liver and lung. (Note the use of a shorter autoradiographic exposure time for adipose tissue in Fig. 6.) Similar results were obtained in $\mathrm{C} 3 \mathrm{H} / \mathrm{HeJ}$ mice (data not shown), indicating that the effects of TGF- $\beta$ were not due to contamination by LPS. The fold induction of PAI- 1 mRNA by TGF- $\beta$ was determined by densitometric scanning and is compared with that of LPS and TNF- $\alpha$ in Table II.

\section{Discussion}

In the studies described here, we have employed a murine model system to examine the expression of PAI-1 mRNA in vivo. Nuclease protection analysis of total RNA extracted from

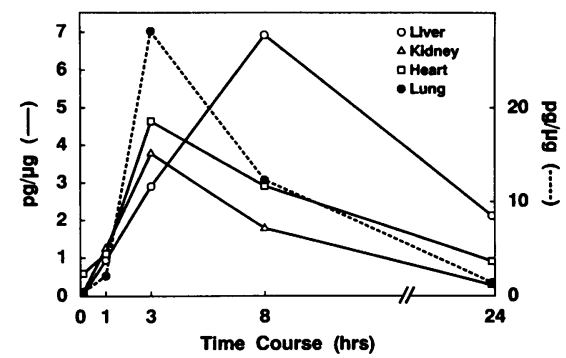

Figure 3. Time course of induction of PAI-1 mRNA by LPS. Mice were injected intraperitoneally with $50 \mu \mathrm{g}$ LPS, the tissues were removed at the indicated times, and total RNA was prepared. The concentration of PAI-1 mRNA was determined by quantitative analysis of ribonuclease protection assay results employing a $\beta$-scanning device (see Methods). Each time point represents the mean of two experiments. Note that the scale employed for the liver, kidney, and heart (left) differs from that employed for the lung (right). 

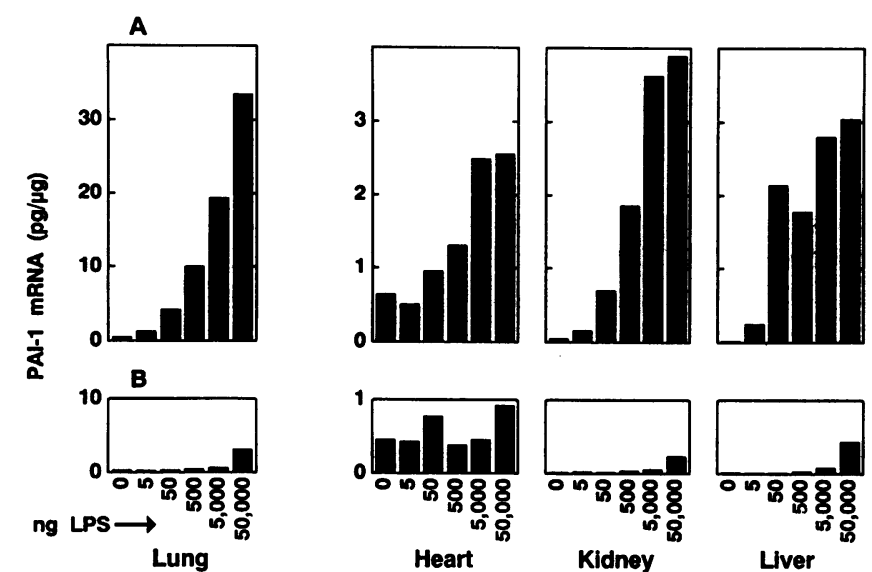

Figure 4. Dose dependency of induction of PAI-1 mRNA by LPS in $\mathrm{CB} 6$ and $\mathrm{C} 3 \mathrm{H} / \mathrm{HeJ}$ mice. $\mathrm{CB} 6(A)$ or $\mathrm{C} 3 \mathrm{H} / \mathrm{HeJ}(B)$ mice were injected intraperitoneally with saline alone as the control (0 dose), or with saline containing increasing amounts of LPS. Tissues were removed $3 \mathrm{~h}$ later for preparation of total RNA, and the concentration of PAI-1 mRNA was determined employing a $\beta$-scanning device (see Methods). Values represent the mean of two experiments. Note that the scale employed for liver, kidney, and heart (right) differs from that employed for the lung (left).

murine tissues (Fig. 1) revealed PAI-1 mRNA to be present in all tissues examined. However, its concentration varied by over 100-fold (Table I). Relatively high concentrations were detected in aorta, heart, lung, and adipose tissue, while lower concentrations were found in kidney, liver, and many other tissues. More limited studies on the tissue distribution of PAI-1 mRNA have been performed in rats (35) and humans (36). In rats, PAI-1 mRNA was detected predominantly in the lung. Lower levels were observed in the heart, while PAI-1 mRNA was undetectable in skeletal muscle, liver, and kidney. In human tissues, PAI-1 mRNA was relatively abundant in myocardium. However, in contrast to murine liver (Table I) or rat liver (35), high message levels were also detected in human liver. This discrepancy may reflect interspecies differences, or possible abnormalities (e.g., acute phase reactions) in the surgical specimens of human liver employed for analysis.

To assess the potential contribution of murine tissues to plasma PAI-1 synthesis, their total PAI-1 mRNA content was calculated (Table I). While the liver contained very low concentrations of PAI- $1 \mathrm{mRNA}(0.021 \mathrm{pg} / \mu \mathrm{g}$ total RNA), it exhibited the highest PAI-1 mRNA content (184 pg), because of its greater yield of total RNA relative to other tissues. However, murine kidney, heart, and lung also contained significant amounts of PAI-1 mRNA (94-106 pg). The PAI-1 mRNA content of other tissues (e.g., aorta, adipose tissue, or skeletal muscle) could not be estimated in full, because, these tissues were not extracted in their entirety. Nonetheless, the apparently high biosynthetic capacity of nonhepatic tissues for PAI-1 (Table I) and the widespread expression of PAI-1 mRNA in murine tissues (Fig. 1) suggests that plasma PAI-1 may originate from multiple tissues in vivo.

The highest concentrations of murine PAI-1 mRNA ( $>2$ $\mathrm{pg} / \mu \mathrm{g}$ ) were detected in the aorta, consistent with observations that PAI-1 is a major biosynthetic product of cultured bovine aortic endothelial cells (37) and smooth muscle cells (38). Newly synthesized PAI-1 is deposited into the extracellular ma- trix of these and other cell types (39-41), where it may protect matrix components from proteolysis by limiting plasmin generation. These observations suggest that PAI-1 may be deposited in vivo within the aortic subendothelium or media, where it may function to preserve the integrity of connective tissue elements, including fibrillar collagen (42). However, the presence of PAI-1 within aortic tissues has yet to be demonstrated, and the identity of the cell types expressing PAI-1 mRNA remains to be established. Interestingly, PAI-1 mRNA was recently localized by in situ hybridization to mesenchymal-appearing cells within human atherosclerotic plaques (43). The synthesis of PAI- 1 by these cells has been postulated to contribute to the development of atherosclerosis (19).

Obesity is an independent risk factor for the development of atherosclerosis and cardiovascular disease (44), and is associated with related metabolic disorders such as hypertriglyceridemia (45), hyperinsulinemia, and noninsulin-dependent diabetes (46). In obese humans, elevations in plasma PAI-1 levels appear to correlate with insulin $(13,15)$. Insulin has been reported to stimulate PAI-1 production by cultured human hepatocytes (47), suggesting that increased hepatic synthesis of PAI-1 may account for its elevation in obese subjects. However, analysis of total RNA prepared from murine tissues (Fig. 1) revealed that high concentrations of PAI-1 mRNA are present in the epididymal fat pad, a large mass of adipose tissue present in the abdominal cavity. In the animals employed for this study, the PAI-1 mRNA content of epididymal fat was approximately one-fifth that of the liver (Table I). In obese animals, the mass of this tissue typically increases severalfold, in which case its biosynthetic capacity for PAI-1 would be ex-
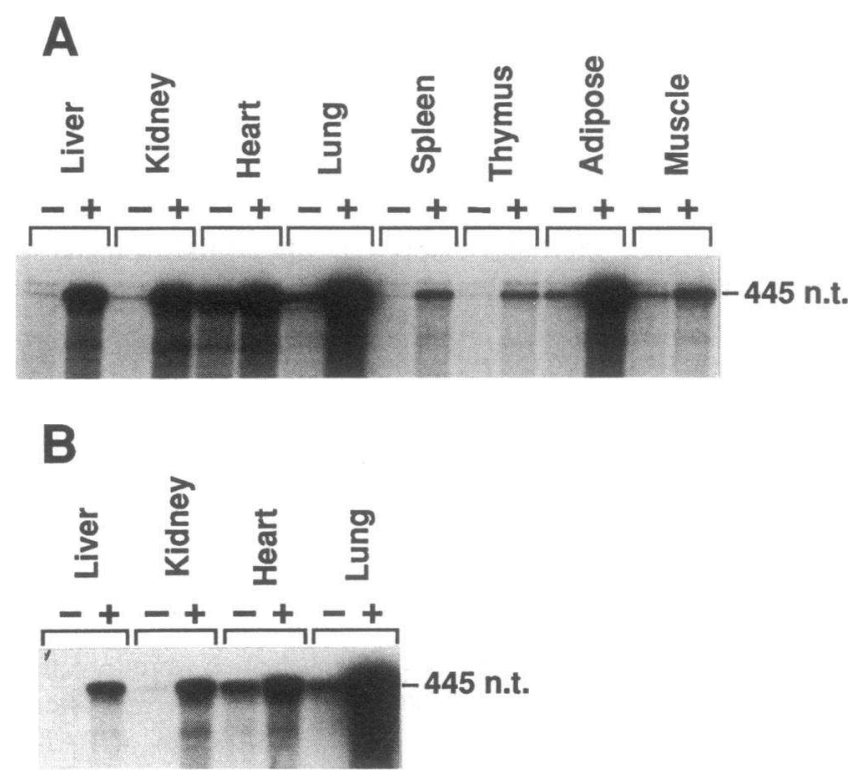

Figure 5. Induction of PAI-1 mRNA by TNF- $\alpha$. CB6 $(A)$ or C3H/HeJ $(B)$ mice were injected intraperitoneally with either recombinant human TNF- $\alpha(4.0 \mu \mathrm{g})$ in saline $(+)$, or saline alone $(-)$, and the indicated tissues were removed at $3 \mathrm{~h}$ postinjection. Total RNA was prepared and $10 \mu \mathrm{g}$ (3.9 $\mu \mathrm{g}$ for adipose tissue) was analyzed for PAI-1 mRNA content by ribonuclease protection assay. The protection fragment corresponding to PAI-1 mRNA (445 nt) is indicated. The minor band migrating slightly above this fragment represents incompletely digested probe and does not correspond to PAI-1 mRNA. The autoradiograms were exposed for $(A) 3 \mathrm{~d}$ and $(B) 1 \mathrm{~d}$. 


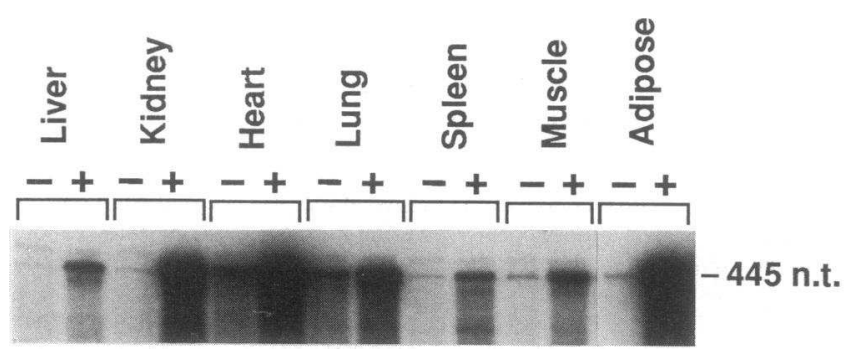

Figure 6. Induction of PAI-1 mRNA by TGF- $\beta$. Mice were injected intravenously with either recombinant human TGF- $\beta(3.0 \mu \mathrm{g})$ in saline $(+)$, or saline vehicle $(-)$, and the tissues were removed at $3 \mathrm{~h}$ postinjection. Total RNA was prepared and analyzed for PAI-1 mRNA content by ribonuclease protection assay. The protection fragment corresponding to PAI-1 mRNA (445 nt) is indicated at the right. Exposure times were varied between tissues to permit optimal visualization of control and induced signals, and were as follows: adipose, $1.5 \mathrm{~d}$; all other tissues, $5 \mathrm{~d}$.

pected to rival that of the liver. These observations raise the possibility that elevations in plasma PAI-1 levels associated with obesity may result from the constitutive synthesis of PAI1 in adipose tissue.

Plasma PAI-1 levels can be dramatically increased in patients with gram-negative sepsis and disseminated intravascular coagulation (5). As a model of gram-negative sepsis, LPS was administered to mice by intraperitoneal injection. As shown in Fig. 2, LPS treatment resulted in the increased accumulation of PAI- 1 mRNA in each of 13 tissues examined. The extent of this response varied considerably between tissues. In particular, LPS treatment led to a profound stimulation of PAI-1 mRNA in the liver, kidney, lung, and adrenals. Of these tissues, the greatest induction of PAI-1 mRNA ( $>300$-fold) was observed in the liver, which also exhibited enhanced sensitivity to the effects of LPS (Fig. 4). These results may reflect the rapid uptake of LPS by hepatic cells, and its increased concentration in the liver relative to other tissues $(48,49)$. However, kinetic analysis revealed the liver responded more slowly to LPS than other tissues, exhibiting maximal levels of PAI-1 mRNA at $\sim 8 \mathrm{~h}$ after LPS treatment, while maximal responses were evident at $3 \mathrm{~h}$ in the kidney, heart, and lung (Fig. 3). Because previous investigations have shown that plasma PAI-1 activity consistently reaches a maximum at $4 \mathrm{~h}$ after LPS challenge in rats (35), rabbits (5), and man (50), the data shown in Fig. 3 suggest that the synthesis of PAI-1 in nonhepatic tissues may be the primary determinant of circulating PAI-1 levels in sepsis. However, because of its high biosynthetic capacity for PAI-1, the liver may also contribute substantially to changes in the plasma PAI-1 pool.

Many of the toxic effects of LPS have been attributed to the actions of TNF- $\alpha$, which is released by cells of monocytic lineage in response to LPS (31). TNF- $\alpha$ suppresses the fibrinolytic activity of endothelial cells by modulating PAI- 1 and t-PA production $(51,52)$, and has been shown to increase plasma PAI-1 levels in rats (52) and human cancer patients (53). Here we report that injection of TNF- $\alpha$ into mice markedly stimulates the accumulation of PAI-1 mRNA, with a tissue-specific response pattern qualitatively similar to that of LPS. Relatively strong increases are elicited by both agents in the liver, kidney, lung, and adrenals (Table II). Moreover, the peak response of PAI-1 mRNA to LPS ( $3 \mathrm{~h}$ in most tissues) follows the peak of
TNF- $\alpha$ activity in plasma, which occurs $\sim 1 \mathrm{~h}$ after LPS injection (54). In $\mathrm{C} 3 \mathrm{H} / \mathrm{HeJ}$ mice, which exhibit an attenuated response of TNF- $\alpha$ to LPS, the response of PAI-1 mRNA was similarly attenuated (Fig. $4 B$ ), while a robust response to TNF$\alpha$ was observed (Fig. $5 B$ ). These results suggest that the effects of LPS on murine PAI-1 gene expression are indirect, and are mediated by TNF- $\alpha$. However, in cultured endothelial cells, LPS has been shown to directly increase PAI-1 mRNA levels independent of de novo protein synthesis (27). We therefore cannot exclude the possibility that the LPS signaling deficit in $\mathrm{C} 3 \mathrm{H} / \mathrm{HeJ}$ mice also attenuates direct effects of LPS on PAI-1 gene expression in vivo.

TGF- $\beta$, which has been implicated in numerous biological processes involving tissue remodeling and wound repair (32), may also mediate the response of PAI-1 mRNA to LPS. In vitro studies have shown that TGF- $\beta$ stimulates PAI-1 biosynthesis in a wide variety of cell types, including endothelial cells (27), smooth muscle cells (55), fibroblasts (56), epithelial cells (57), and several transformed cell lines, including hepatoma cells (58). In vivo, TGF- $\beta$ is present in platelets (32), peripheral blood monocytes, and tissue macrophages (33), and is released upon activation of these cells. Because experimental infusion of TGF- $\beta$ has been demonstrated to increase plasma PAI-1 activity in rabbits (34), we investigated the response of the murine PAI- 1 gene to TGF- $\beta$. Injection of purified, recombinant human TGF- $\beta$ stimulated the accumulation of PAI-1 mRNA in numerous tissues. Strong induction was observed in adipose tissue and kidney (Fig. 6), while a relatively modest induction was apparent in the liver and lung. In contrast, LPS and TNF- $\alpha$ elicited strong responses in these tissues (Figs. 2 and 5). These results indicate that TGF- $\beta$ exerts selective effects on PAI-1 gene expression distinct from those of LPS or TNF- $\alpha$, and is therefore unlikely to mediate the response of PAI- 1 to LPS in tissues such as the liver and lung. However, the responsiveness of the PAI- 1 gene to TGF- $\beta$ in a wide variety of cultured cell types, as opposed to the relatively limited specificity of LPS and TNF- $\alpha$ (2), suggests that TGF- $\beta$ may promote PAI- 1 synthesis in additional cell types in vivo.

In previous studies, we have shown that LPS, TNF- $\alpha$, and TGF- $\beta$ directly increase the steady-state level of PAI- 1 mRNA in cultured endothelial cells by stimulating PAI-1 gene transcription (27). In this report, we have extended these observations to show that each of these agents increases PAI- 1 mRNA levels in a broad spectrum of murine tissues, consistent with its increased expression in vascular cells. The action of these agents may lead to local or systemic alterations in fibrinolytic activity during gram-negative sepsis, inflammation, and thrombosis, and contribute to pathophysiologic fibrin deposition and extracellular matrix accumulation in association with these processes. Elucidation of the mechanisms regulating expression of the PAI-1 gene in vivo will enable further investigation of its role in vascular disease.

\section{Acknowledgements}

We gratefully acknowledge the technical assistance of Karen Crain, the secretarial assistance of Peggy Tayman, and the generosity of Dr. Michael Cole in providing the murine PAI-1 cDNA.

This work was supported by a postdoctoral fellowship (training grant T32 AI-07244) awarded to Dr. Sawdey, and by research grants HL-22289 and HL-16411 awarded to Dr. Loskutoff, from the National Institutes of Health, Bethesda, MD. This is publication number 6773CVB from the Research Institute of Scripps Clinic. 


\section{References}

1. Hekman, C. M., and D. J. Loskutoff. 1988. Kinetic analysis of the interactions between plasminogen activator inhibitor 1 and both urokinase and tissue plasminogen activator. Arch. Biochem. Biophys. 262:199-210.

2. Loskutoff, D. J., M. Sawdey, and J. Mimuro. 1989. Type 1 plasminogen activator inhibitor. In Progress in Hemostasis and Thrombosis. B. Coller, editor. Bermedica Production, Columbia, MD. 9:87-115.

3. Schleef, R. R., D. L. Higgins, E. Pillemer, and J. J. Levitt. 1989. Bleeding diathesis due to decreased functional activity of type 1 plasminogen activator inhibitor. J. Clin. Invest. 83:1747-1752.

4. Dieval, J., G. Nguyen, S. Gross, J. Delobel, and E. K. O. Kruithof. 1991. A lifelong bleeding disorder associated with a deficiency of plasminogen activator inhibitor type 1. Blood. 3:528-532.

5. Colucci, M., J. A. Paramo, and D. Collen. 1985. Generation in plasma of a fast-acting inhibitor of plasminogen activator in response to endotoxin stimulation. J. Clin. Invest. 75:818-824.

6. Kruithof, E. K. O., C. Tran-Thang, A. Gudinchet, J. Hauert, G. Nicoloso, C. Genton, H. Welti, and F. W. Bachmann. 1987. Fibrinolysis in pregnancy. A study of plasminogen activator inhibitors. Blood. 69:460-466.

7. Wiman, B., and J. Chmielewska. 1985. A novel fast inhibitor to tissue plasminogen activator in plasma, which may be of great pathophysiological significance. Scand. J. Clin. Lab. Invest. 177:43-47.

8. Juhan-Vague, I, J. Valadier, M. C. Alessi, M. F. Aillaud, J. Ansaldi, C Philips-Joet, P. Holvoet, A. Serradimigni, and D. Collen. 1987. Deficient t-PA release and elevated PA inhibitor levels in patients with spontaneous or recurrent deep venous thrombosis. Thromb. Haemostasis. 57:67-72.

9. Aillaud, M. F., I. Juhan-Vague, M. C. Alessi, M. Marecal, M. F. Vinson, C. Arnaud, P. H. Vague, and D. Collen. 1985. Increased PA-inhibitor levels in the postoperative period- no cause-effect relation with increased cortisol. Thromb. Haemostasis. 54:466-468.

10. Kluft, C., J. H. Verheijen, A. F. H. Jie, D. C. Rijken, F. E. Preston, H. M. Sue-Ling, J. Jespersen, and A. D. Aasen. 1985. The postoperative fibrinolytic shutdown: a rapidly reverting acute phase pattern for the fast-acting inhibitor of tissue-type plasminogen activator after trauma. Scand. J. Clin. Lab. Invest. 45:605-610.

11. Sprengers, E. D., and C. Kluft. 1987. Plasminogen activator inhibitors Blood. 69:381-387.

12. Almer, L., and H. Ohlin. 1987. Elevated levels of the rapid inhibitor of plasminogen activator (t-PAI) in acute myocardial infarction. Thromb. Res. 47:335-339.

13. Vague, P., I. Juhan-Vague, M. F. Aillaud, C. Badier, R. Viard, M. C. Alessi, and D. Collen. 1986. Correlation between blood fibrinolytic activity, plasminogen activator inhibitor level, plasma insulin level and relative body weight in normal and obese subjects. Metabolism. 35:250-253.

14. Auwerx, J., R. Bouillon, D. Collen, and J. Geboers. 1988. Tissue-type plasminogen activator inhibitor activity in diabetes mellitus. Arteriosclerosis. 8:68-72.

15. Juhan-Vague, I., P. Vague, M. C. Alessi, C. Badier, J. Valadier, M. F. Aillaud, and D. Atlan. 1987. Relationship between plasma insulin, triglyceride, body mass index, and plasminogen activator inhibitor 1. Diabetes Metab. 13:331-336.

16. Hamsten, A., B. Wiman, U. deFaire, and M. Blomback. 1985. Increased plasma levels of a rapid inhibitor of tissue plasminogen activator in young survivors of myocardial infarction. $N$. Engl. J. Med. 313:1557-1563.

17. Paramo, J. A., M. Colucci, and D. Collen. 1985. Plasminogen activator inhibitor in the blood of patients with coronary artery disease. Br. Med. J. 291:573-574.

18. Oseroff, A., C. Krishnamurti, A. Hassett, D. Tang, and B. Alving. 1989. Plasminogen activator and plasminogen activator inhibitor activities in men with coronary artery disease. J. Lab. Clin. Med. 113:88-93.

19. Sawdey, M., and D. J. Loskutoff. 1991. Regulation of type 1 plasminogen activator inhibitor gene expression in cultured endothelial cells and the vessel wall. In Atherosclerosis: Cellular and Molecular Interactions in the Artery Wall. A. Gotlieb, B. L. Langille, and S. Fedoroff, editors. Plenum Press, New York 1:187-208.

20. Hamsten, A., U. De Faire, G. Walldius, G. Dahlen, A. Szamosi, C. Landou, M. Blomback, and B. Wiman. 1987. Plasminogen activator inhibitor in plasma: risk factor for recurrent myocardial infarction. Lancet ii:3-9.

21. Loskutoff, D. J. 1991. Regulation of PAI-1 gene expression. Fibrinolysis. In press.

22. Chomczynski, P., and N. Sacchi. 1987. Single-step method of RNA isolation by acid guanidinium thiocyanate-phenol-chloroform extraction. Anal. Biochem. 162:156-159.

23. Prendergast, G. C., L. E. Diamond, D. Dahl, and M. D. Cole. 1990. The c-myc-regulated gene mrl encodes plasminogen activator inhibitor 1. Mol. Cell. Biol. 10:1265-1269.

24. Mroczka, D. L., B. Cassidy, H. Busch, and L. I. Rothblum. 1984. Characterization of rat ribosomal DNA. J. Mol. Biol. 174:141-162.
25. Gilman, M. 1991. Current Protocols in Molecular Biology. F. M. Ausubel, R. Brent, R. E. Kingston, D. D. Moore, J. G. Seidman, J. A. Smith, and K. Struhl, editors. J. Wiley \& Sons, New York. Vol. 1, unit 4.7.

26. Feinberg, A. P., and B. Vogelstein. 1983. A technique for radiolabeling DNA restriction endonuclease fragments to high specific activity. Anal. Biochem. 132:6-13.

27. Sawdey, M., T. J. Podor, and D. J. Loskutoff. 1989. Regulation of type 1 plasminogen activator inhibitor gene expression in cultured bovine aortic endothelial cells: induction by transforming growth factor- $\beta$, lipopolysaccharide, and tumor necrosis factor- $\alpha$. J. Biol. Chem. 264:10396-10401.

28. Emeis, J. J., and T. Kooistra. 1986. Interleukin 1 and lipopolysaccharide induce an inhibitor of tissue-type plasminogen activator in vivo and in cultured endothelial cells. J. Exp. Med. 163:1260-1266.

29. Suffredini, A. F., P. C. Harpel, and J. E. Parrillo. 1989. Promotion and subsequent inhibition of plasminogen activation after administration of intravenous endotoxin to normal subjects. $N$. Engl. J. Med. 320:1165-1172.

30. Beutler, B., N. Krochin, I. W. Milsark, C. Luedke, and A. Cerami. 1986. Control of cachectin (Tumor Necrosis Factor) synthesis: mechanisms of endotoxin resistance. Science (Wash. DC). 232:977-980.

31. Beutler, B., and A. Cerami. 1987. Cachectin: more than a tumor necrosis factor. N. Engl. J. Med. 316:379-385.

32. Sporn, M. B., A. B. Roberts, L. M. Wakefield, and B. de Crombrugghe 1987. Some recent advances in the chemistry and biology of transforming growth factor- $\beta$. J. Cell Biol. 105:1039-1045.

33. Assoian, R. K., B. E. Fleurdelys, H. C. Stevenson, P. J. Miller, D. K Madtes, E. W. Raines, R. Ross, and M. B. Sporn. 1987. Expression and secretion of type $\beta$ transforming growth factor by activated human macrophages. Proc. Natl. Acad. Sci. USA. 84:6020-6024.

34. Fujii, S., and B. E. Sobel. 1990. Induction of plasminogen activator inhibitor by products released from platelets. Circulation. 82:1485-1493.

35. Quax, P. H. A., C. M. van den Hoogen, J. H. Verheijen, T. Padro, R. Zeheb, T. D. Gelehrter, T. J. C. van Berkel, J. Kuiper, and J. J. Emeis. 1990 Endotoxin induction of plasminogen activator and plasminogen activator inhibitor type $1 \mathrm{mRNA}$ in rat tissues in vivo. J. Biol. Chem. 265:15560-15563.

36. Lucore, C. L., S. Fujii, T. C. Wun, B. E. Sobel, and J. J. Billadello. 1988 Regulation of the expression of type 1 plasminogen activator inhibitor in Hep G2 cells by epidermal growth factor. J. Biol. Chem. 263:15845-15848.

37. Loskutoff, D. J., J. A. van Mourik, L. A. Erickson, and D. A. Lawrence. 1983. Detection of an unusually stable fibrinolytic inhibitor produced by bovine endothelial cells. Proc. Natl. Acad. Sci. USA. 80:2956-2960.

38. Laug, W. E. 1985. Vascular smooth muscle cells inhibit plasminogen activators secreted by endothelial cells. Thromb. Haemostasis. 53:165-169.

39. Knudsen, B. S., P. C. Harpel, and R. L. Nachman. 1987. Plasminogen activator inhibitor is associated with the extracellular matrix of cultured bovine smooth muscle cells. J. Clin. Invest. 80:1082-1089.

40. Laiho, M., O. Saksela, and J. Keski-Oja. 1987. Transforming growth factor- $\beta$ induction of type 1 plasminogen activator inhibitor. J. Biol. Chem. 262:17467-17474.

41. Mimuro, J., R. R. Schleef, and D. J. Loskutoff. 1987. The extracellular matrix of cultured bovine aortic endothelial cells contains functionally active type 1 plasminogen activator inhibitor. Blood. 70:721-728.

42. Eeckhout, Y., and G. Vaes. 1977. Further studies on the activation of procollagenase, the latent precursor of bone collagenase. Biochem. J. 166:21-31.

43. Gordon, D., A. J. Augustine, K. M. Smith, S. M. Schwartz, and J. N. Wilcox. 1989. Localization of cells expressing tPA, PAIl, and urokinase by in situ hybridization in human atherosclerotic plaques and in the normal rhesus monkey. Thromb. Haemostasis. 62:131.

44. Hubert, H. B., M. Feinleib, P. M. McNamara, and W. P. Castelli. 1983. Obesity as an independent risk factor for cardiovascular disease: a 26-year followup of participants in the Framingham heart study. Circulation. 67:968-977.

45. Castelli, W. P. 1988. The triglyceride issue: a view from Framingham. Am. Heart J. 112:432-437.

46. Bjorntorp, P. 1990. "Portal" adipose tissue as a generator of risk factors for cardiovascular disease and diabetes. Arteriosclerosis. 10:493-496.

47. Kooistra, T., P. J. Bosma, H. A. M. Tons, A. P. van den Berg, P. Meyer, and H. M. G. Princen. 1989. Plasminogen activator inhibitor 1 biosynthesis and mRNA level are increased by insulin in cultured human hepatocytes. Thromb. Haemostasis. 62:723-728.

48. Mathison, J. C., and R. J. Ulevitch. 1979. The clearance, tissue distribution, and cellular localization of intravenously injected lipopolysaccharide in rabbits. J. Immunol. 123:2133-2143.

49. Musson, R. A., D. C. Morrison, and R. J. Ulevitch. 1978. Distribution of endotoxin (lipopolysaccharide) in the tissues of lipopolysaccharide-responsive and -unresponsive mice. Infect. Immun. 21:448-457.

50. van Deventer, S. J. H., H. R. Buller, J. W. ten Cate, L. A. Aarden, C. E. Hack, and A. Sturk. 1990. Experimental endotoxemia in humans: analysis of cytokine release and coagulation, fibrinolytic, and complement pathways. Blood. 76:2520-2526. 
51. Schleef, R. R., M. P. Bevilacqua, M. Sawdey, M. A. Gimbrone, Jr., and D. J. Loskutoff. 1988. Cytokine activation of vascular endothelium: effects on tissue-type plasminogen activator and type 1 plasminogen activator inhibitor. $J$. Biol. Chem. 263:5797-5803.

52. van Hinsbergh, V. W. M., T. Kooistra, E. A. van den Berg, H. M. Princen, W. Fiers, and J. J. Emeis. 1988. Tumor necrosis factor increases the production of plasminogen activator inhibitor in human endothelial cells in vitro and in rats in vivo. Blood. 72:1467-1473.

53. van Hinsbergh, V. W. M., K. A. Bauer, T. Kooistra, C. Kluft, G. Dooijewaard, M. L. Sherman, and W. Nieuwenhuizen. 1990. Progress of fibrinolysis during tumor necrosis factor infusions in humans. Concomitant increase in tissue-type plasminogen activator, plasminogen activator inhibitor type-1, and fibrin(ogen) degradation products. Blood. 76:2284-2289.

54. Remick, D. G., R. M. Strieter, J. P. Lynch, D. Nguyen, M. Eskandari, and S. L. Kunkel. 1989. In vivo dynamics of murine tumor necrosis factor- $\alpha$ gene expression: kinetics of dexamethasone-induced suppression. Lab. Invest. 60:766771.
55. Reilly, C. F., and R. C. McFall. 1991. Platelet-derived growth factor and transforming growth factor- $\beta$ regulate plasminogen activator-1 synthesis in vascular smooth muscle cells. J. Biol. Chem. 266:9419-9427.

56. Lund, L. R., A. Riccio, P. A. Andreasen, L. S. Nielsen, P. Kristensen, M. Laiho, O. Saksela, F. Blasi, and K. Dano. 1987. Transforming growth factor- $\beta$ is a strong and fast acting positive regulator of the level of type-1 plasminogen activator inhibitor mRNA in WI-38 human lung fibroblasts. EMBO (Eur. Mol. Biol. Organ.) J. 6:1281-1286.

57. Thalacker, F. W., and M. Nilsen-Hamilton. 1987. Specific induction of secreted proteins by transforming growth factor- $\beta$ and 12-O-tetradecanoylphorbol-13-acetate. J. Biol. Chem. 262:2283-2290.

58. Westerhausen, D. R., W. E. Hopkins, and J. J. Billadello. 1991. Multiple transforming growth factor- $\beta$-inducible elements regulate expression of the plasminogen activator inhibitor type-1 gene in Hep G2 cells. J. Biol. Chem. 266:1092-1100. 